\title{
Protein gene patent faces challenge in court
}

Munich. Amgen's European patent of the gene responsible for the protein erythropoietin is being challenged by Genetics Institute (GI) on the grounds that it lacks the necessary 'inventive step'. GI says that Amgen was able to discover the gene because it had access to the only supplies of the human form of the protein.

The claim is one of several being made in the final chapters of legal wranglings between the Californian-based Amgen and GI, based in Boston, over the rights to erythropoietin. The protein, which stimulates the production of red blood cells from bone marrow and is used to treat anaemias, has an estimated world market of US $\$ 2$ billion and a European market of US\$500 million.

Last month, the European Patent Office appeals board heard evidence on a series of challenges launched against Amgen by GI and five other companies. The board took the unusual step of delaying the ruling on the grounds that the issues involved were too complex for an immediate decision. Its verdict is expected on 21 November.

The dispute between GI and Amgen over erythropoietin has been long and bitter. GI was first granted a US patent for a pharmaceutical preparation of the protein in a highactivity homogeneous form in 1987. A European patent followed in 1992.

GI was also engaged in a close-run race with Amgen to clone the erythropoietin gene. The task was complicated by the difficulties of obtaining a pure source of the protein for cloning. Erythropoietin is produced in sig- nificant quantities only in patients suffering from anaemia, when the body tries to rebuild its damaged red blood cell count.

Such patients are usually treated immediately. But Amgen secured supplies of erythropoietin extracted from the urine of three untreated Japanese patients suffering from aplastic anaemia, an often-fatal blood disorder.

Amgen's move allowed it to design oligonucleotide probes that were suitable for genomic screening, one of several methods of cloning. The company was granted a US patent on the gene in 1987 and a European patent in 1990 .

Opponents argue that the knowledge and technology for cloning the gene were all openly available. Simply gaining access to the source of the protein does not constitute an inventive step, they argue, a requirement for a European patent

Amgen dismisses this by saying that its competitors had simply not thought of using this source of erythropoietin, and that its inventive step was to realize that the source could be acquired and used.

Opponents also claim that Amgen did not disclose sufficient information to allow others to repeat the work "without undue burden", another criterion for a European patent. There were mistakes in the sequence of the described genomic DNA and Amgen did not publish the entire sequence, including regulatory coding regions. Moreover, Amgen described the plasmids that it used incompletely and with some errors, although the company claims that any mistakes do not significantly effect the outcome of the procedures it describes.

Opponents also say that Amgen should have deposited its clone in a publicly accessible repository at the time of US patent filing. Amgen counterargues that its gene is sufficiently described in its patent.

Amgen and GI both feel their patent entitles them to a monopoly of the erythropoietin market. The two companies have been in litigation since 1991, but Amgen's patent has so far proved the more robust, having survived several challenges on both sides of the Atlantic. Amgen now controls all US supplies of the protein and shares the European market with GI's licensee Boehringer Mannheim.

GI lost its original 1987 US patent in 1991 , on the grounds that the defined specific activity of its product could not be reproduced by others on the basis of information the company had disclosed in their patent. It was granted a new patent on essentially the same product, but without numerically defining the specific activity, this summer.

At this point, more legal suits started flying. Amgen took out an injunction against GI to prevent it from selling erythropoietin in the United States. And GI filed suit against Amgen's US marketing partner Orthopharmaceuticals for infringing its new patent. If Amgen's patent is upheld in Europe, Boehringer Mannheim will have to bear heavy fines for its infringement.

Alison Abbott

\section{'Ig' Nobel awards celebrate irredeemable research}

Boston. As the Nobel prize award committees were polishing their press releases in Stockholm, on the other side of the Atlantic 1,200 spectators crammed into the Kresge Auditorium of the Massachusetts Institute of Technology on 6 October for Fourth First Annual Ig Nobel Prize Ceremony.

A total of 10 Ig Nobel Prizes were handed out for "irregular, irredeemable, or irreproducible achievements in science, technology, and other irreproachable disciplines". Marc Abrahams, editor of The Annals of Improbable Research (AIR), published by the MIT Museum, described such achievements as "crying out" for recognition.

Robert Lopez, a veterinarian from Westport, New York, captured the entomology prize for experiments in which he inserted ear mites from cats into his ear and painstakingly observed the results. "Immediately, I heard scratching sounds, then moving sounds, as the mites began to explore my ear canal," Lopez reports.

Lopez survived the ordeal and showed up to receive his "Ig," generously offering to distribute ear mites among the crowd.

Bob Glasgow, a state senator from Texas, won the chemistry award for sponsoring drug-control legislation which now makes it illegal to purchase beakers, flasks, test tubes and other glassware without a special permit. Tim Mitchell of Corning, Inc. was present to receive the prize and praise the new bill.

"It always starts with a test tube, but suddenly that's not enough," Mitchell noted. "Before you know it, you're lying with a beaker in one hand, a flask in the other, strung out and begging for grant money." But he warned that bans on laboratory equipment can be a slippery slope. "Where will it end? Will pocket protectors be next? Remember, beakers don't hurt people. People hurt people."

The prize ceremony provided a unique opportunity to see a live performance of "The Interpretive Dance of the Electrons", featuring three bonafide Nobel Laureates: Dudley Herschbach, William Lipscomb and Richard Roberts. Partici- pants were also treated to a procession of 'Ignitaries' that includes NonExtremists for Moderate Change in Finland, the Boston Pig Latin Chorus and the 21st-Century Center for 20th-Century Astrology.

The Heisenberg Certainty Lectures were another irreproducible feature of the ceremony. In a 30-second soliloquy, Lipscomb warned the US Congress that "if your position is everywhere, your momentum is zero". Astrophysicist Margaret Geller explained that "everything you've heard about the universe is false". Marvin Minsky, the guru of artificial intelligence, was heckled offstage owing to the dearth of humour in his deliberately ponderous presentation.

In the midst of this excitement, it was easy to forget the runners-up - improbable researchers who didn't quite make the grade. For these Ig hopefuls, Abrahams offered some encouragement: "If you can't help yourself, by all means continue your efforts. If your work is truly irredeemable, one day its worth will be fully appreciated." Steve Nadis 